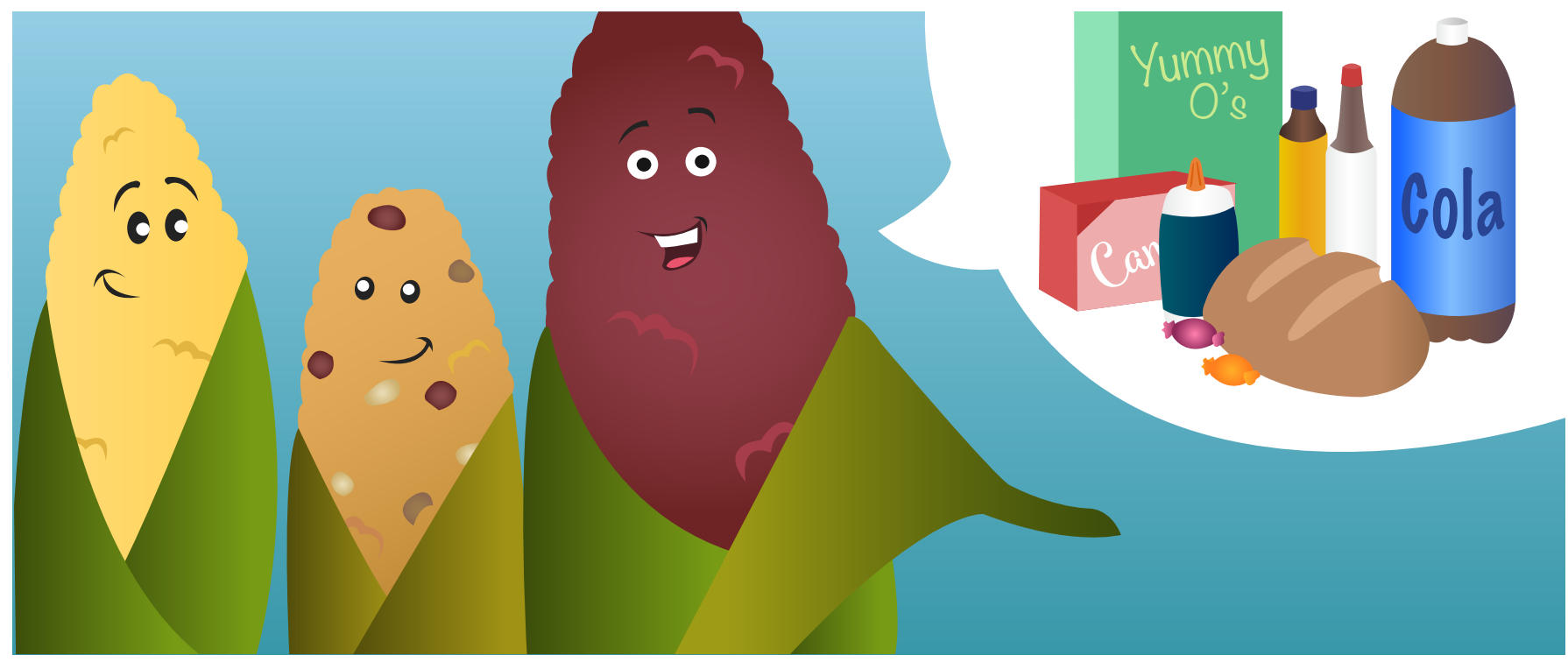

\title{
THERE IS MORE TO CORN THAN POPCORN AND CORN ON THE COB!
}

\section{Alma Piñeyro-Nelson ${ }^{1,2 *}$, Daniela Sosa-Peredo ${ }^{1,2}$, Emmanuel González-Ortega ${ }^{2,3}$ and Elena R. Álvarez-Buylla ${ }^{2,4}$}

${ }^{1}$ Department of Food and Animal Production, Universidad Autónoma Metropolitana Xochimilco, Mexico City, Mexico, ${ }^{2}$ Center for Complexity Sciences (C3), National Autonomous University of Mexico, Mexico City, Mexico, ${ }^{3}$ National Institute of Ecology and Climate Change, Mexico City, Mexico, ${ }^{4}$ Ecology Institute, National Autonomous University of Mexico, Mexico City, Mexico

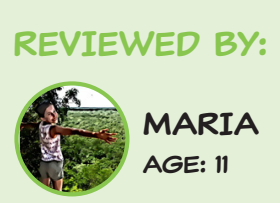

Corn (also called maize) is a useful plant that is part of the grass family (called Poaceae). Corn was first produced in what is now Mexico around 6,000 years ago, from a weed called teosinte. While corn and teosinte share many features, the "cob" present in corn, on which many grains or kernels are attached, is a unique feature of corn. Some of the biggest differences between teosinte and corn are due to human farming practices and selection of teosinte mutants. Corn is dependent on human assistance for its survival, while many pre-Columbian civilizations relied on it for their nutrition. Nowadays, corn continues to be one of the most important grain crops in the world, and corn is a central part of the diet of many people. In some cases, corn is eaten as a side dish, and in some places like Mexico, Central America, Colombia, and some African countries, corn makes up the main component of their cuisine. Such diverse cuisine relies, in turn, on the use of hundreds of different maize varieties, called landraces, which need different growth conditions and differ in color, size, and flavor. On the American continent, landraces are kept and actively modified by small 
farmers. These local farming methods are very important for maintaining the genetic diversity of corn, which needs to be understood and protected to adapt to the changes in the environment that are likely to happen in the future, due to climate change.

\section{CORN: A UNIQUE MEMBER OF A VERY POPULAR PLANT FAMILY}

Corn-also known as maize, goes by the scientific name Zea mays subsp. mays, and is a part of the grass family or Poaceae. With approximately 12,000 species [1], the grass family has members almost all over the world. You can find grasses almost anywhere: your front lawn, the prairies, the African savannah, many forests and deserts, near the ocean and up high in the mountains.

While corn is quite special in its own way, it is not the only important crop that is part of the grass family. All edible species of rice, wheat, millet, rye, barley, sorghum, oats, even bamboo and last but not least, sugarcane, are members of the Poaceae.

Corn is a plant that humans have helped to create over thousands of years. It is very unlikely that corn would exist, as we know it today, without human help. While you may think that plants humans grow for food are always pretty dependent on human hands for their survival and reproduction, many of these

\section{DOMESTICATION}

Is a multi-generational process in which a plant or animal population is taken from the wild and maintained by humans. One generation after another, a domesticated species is selectively bred to accumulate particular traits that are useful to us.

\section{MUTANTS}

A mutant is an individual that has suffered a change in its genes, such that it has different nucleotides in particular genes, when compared with other individuals of the same species. Mutations can potentially translate into differences in shape, growth patterns, susceptibility to disease, with respect to other individuals that do not have a particular mutation. plants could happily live back in the wild. But this is definitely not the case for corn, and there are good reasons why! Keep reading to find out.

\section{THE GENETIC ORIGINS OF CORN}

Corn and its cob are quite unique within the grass family. Think about the spike of wheat or rice. They look very different from a corn's cob and even if we take a look at corn's closest relatives, tall, weedy grasses called teosintes, their "cobs" and kernels look nothing like corn's! Teosinte cobs have few seeds, and each seed is covered with a hard shell made of silica (the same material glass is made of), which is quite good for surviving fire, drought, and even being ingested by animals. By contrast, corn has "naked" seeds, and its cob is the product of the movement, during development, of the silica seed covers to the bottom of the kernel, forming a massive, tough structure (called a spike), from which kernels cannot get loose (see Figure 1 for a comparison). The cause of this huge change from the structure of teosinte to corn is actually simple: during the long process of creating corn for human use, called domestication, without knowing they were doing it, humans selected those teosinte plants that had a mutation in a gene called teosinte glume architecture 1 (tga1). This gene guides silica formation around the seed and humans selected atypical forms of teosinte plants (mutants) where this gene did not 


\section{FIGURE 1}

In this figure you can see a comparison of rice, wheat, teosinte, and corn spikes. A seed for each grass is also drawn. Note how different corn's spike is from the other type of spikes. In the case of teosinte and corn, look at the differences in the number and shape of their seeds. Corn, in contrast with teosinte, has a

"naked" seed, with only a little part of the silica shell present where it attaches to the cob (right). Rice and wheat appear larger than they really are. Figure by Luis Fernando Sobrado/ Zemperi.

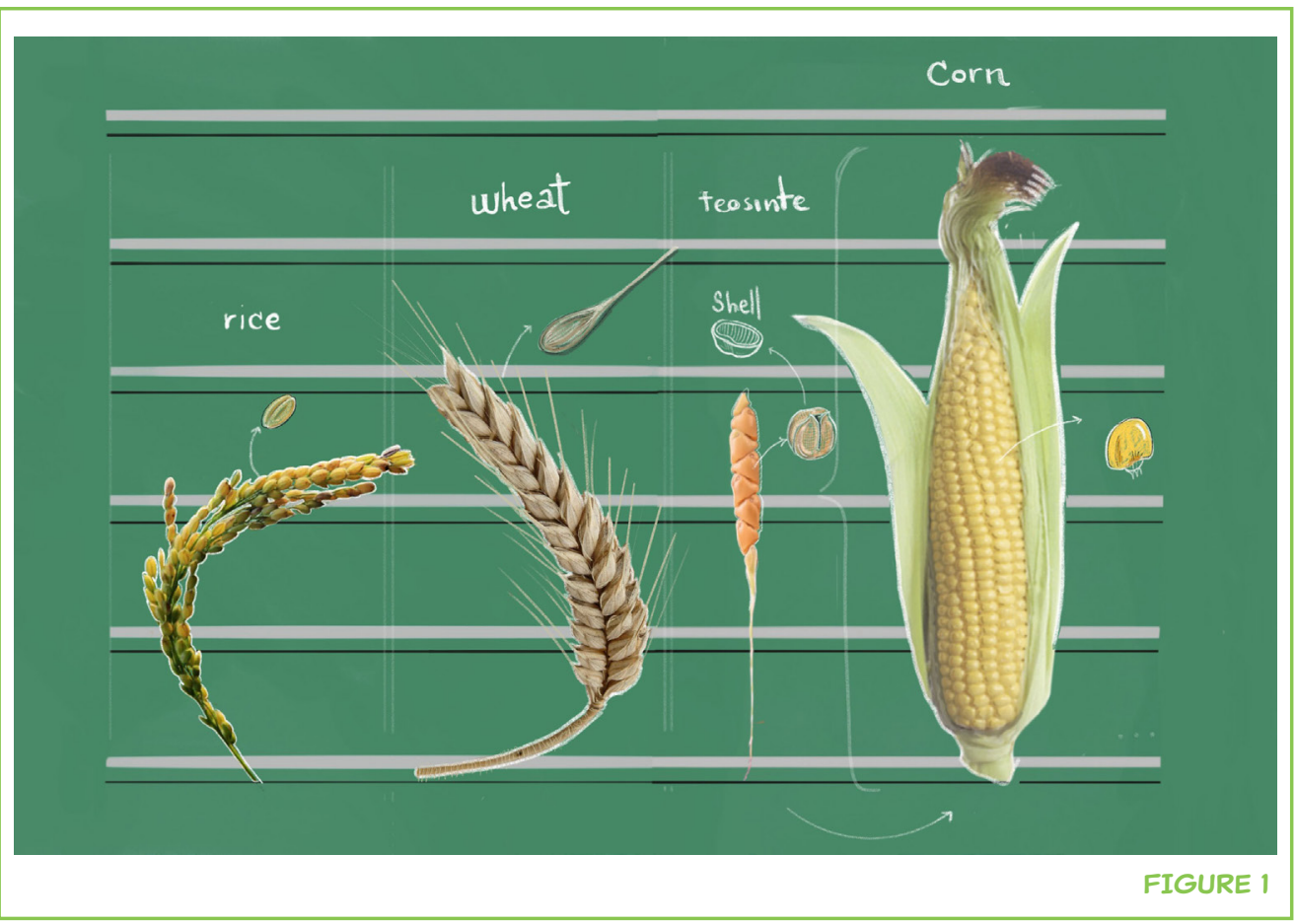

produce as much tgal protein, which translated into loosing the silica cover but gaining a cob [2].

Another difference between corn and teosinte is that corn is covered by multiple layers of husk leaves, which prevents small animals and birds from eating and spreading the seeds. In teosinte, the husk will eventually open by itself, but the husks of corn never completely open by themselves. We, humans, have to open them. Corn has also evolved to differ in other ways from teosinte. For example, corn typically has a single stalk instead of many stalks. These two traits-a leafy husk and a single stalk, are related and came to exist together in the corn plant through human selection of teosinte plants that happened to have mutations in another gene called teosinte branched 1 (tb1). The mutant version of tb1 creates plants that have something called apical dominance, in which branches on the stalk are suppressed, and additional layers of leaves are added to the cob [2]. It has also been shown that corn and teosinte have different kinds of soil microorganisms associated with them. Read more about this in the Frontiers for Young Minds article by Jennifer Schmidt and Amélie Gaudin.

So, how long ago did corn, as we know it, come to exist? We can use a scientific approach called genetics to estimate when corn originated. In genetics, we study genes, which are the hereditary particles that are passed along one generation after another through sexual reproduction. These genes encode the instructions to produce all of the proteins that make us who we are. Comparing changes in genes from one organism against another, we can unravel part of the common history of their lineages. In fact, we can use genetics to study 
GENETIC

DIVERSITY

Refers to the total number of genetic variants present in individuals from a particular species. Preserving genetic diversity is an important conservation target, as it can help individuals from a given species adapt to changing conditions or environments.

1 http://www.fao.org/ statistics/databases/. the history of any organism that has DNA. Genetic studies of corn are easier than studies of wild plants because corn has been used, moved, and stored by humans throughout its evolutionary history. Because of its widespread use, corn remains have been found in many archeological sites. Thus, archeology is another source of historical information as to when and how this plant was "taken into a home"... or domesticated. In the case of corn, its oldest recorded remains-fossilized cobs-have been estimated to be around 6,000 years old [3]. These very old cobs were found in a cave in Guilá Naquitz, in the Mexican state of Oaxaca, Mexico [3]. This evidence and other scientific data have told us that Mexico is considered the center of origin and diversification of corn and harbors about half of all the genetic diversity (genetic variants) of this crop in the American continent [4]. We will later explain why this is so important to keep in mind in Section "Corn Landraces, Beautiful, Diverse, and Necessary for a Changing Climate!”

\section{THE IMPORTANCE OF CORN IN THE HUMAN DIET: THEN AND NOW}

The domestication of corn on the American continent was a huge deal for the people living in this part of the world, as this plant became a very important crop for most pre-Columbian civilizations until the Europeans came to the Americas (which happened in 1492 A.C.). In pre-Columbian times, only the potato had a similar role in the Inca Empire, located in what is now Peru and Bolivia. Corn's importance in the diet and in the farming practices of pre-Columbian civilizations on the American continent is similar to the role of wheat and rice as staple crops in ancient civilizations in the Middle East, Europe, and different parts of Asia. Nowadays, these three crops, corn, wheat, and rice, are still the main components of the human diet around the world, and they provide important sources of nutrients for the great majority of the world's population.

So, currently, which countries are the top corn producers in the world? According to recent data, China and the United States have the highest maize production worldwide, with 200 and 300 million tons per year, respectively, followed by some Latin American countries. Brazil, Argentina, and Mexico have a production of 79, 33, and 23 million tons per year, respectively. ${ }^{1}$

Nowadays, many of us think about corn grains as food for chickens, pigs, and other farm animals, but corn has many other uses. In the food industry, corn starch, derived from ground corn kernels, is added into various foods such as pasta, candies, sauces, breads, soups, stews, and baby food. Some edible oils and syrups are also made from corn, such as fructose and other sweeteners, used in most sodas or even juices sold in supermarkets. Processed corn is also used in medicines, cosmetics, glues, paper, textiles, 
2 http://www.worldofcorn. com/\#/.

3 https://ich.unesco.org/ en/RL/traditionalmexican-cuisineancestral-ongoingcommunity-culture-themichoacanparadigm-00400.

\section{LANDRACE}

Is a plant (or animal) variety that has been bred and selected by humans over time to grow in a specific environment, after its isolation from other populations of the same species.

\section{FIGURE 2}

This figure shows to the left, some of the uses of corn as a food additive, where it is used as a sweetener in bread, soda, $B B Q$ sauces, pasta sauce, or as corn oil. In comparison in the right side of the image, the use of corn as a main ingredient in foods is portrayed. In this case, corn is used not only for snacks like popcorn and nachos but also for many traditional dishes like tortillas, stuffed tortillas ("flautas"), and soups like "pozole." Figure by Luis Fernando Sobrado/ Zemperi.

paints, and solvents. ${ }^{2}$ Corn residues or "scraps" have recently been used to create biodegradable materials similar to plastics. Another use for corn is to use its sugars to make biodiesel fuel for use in cars and other vehicles.

So, not only can we eat corn as an additive mixed into different foods, or as a side dish like delicious corn on the cob, or grits, or as a snack in the form of nachos and popcorn: around the world, there are many dishes-and culturesthat totally revolve around corn. In such cultures, corn is a central component of their cuisines. We will talk about this in the next section!

\section{CORN-BASED CUISINE: DIVERSE AND YUMMY!}

In countries such as Mexico, most of Central America, Colombia, and several countries in Africa, corn-based foods are eaten every day. In places like Mexico, you can even have a three-course meal with each plate having some (or a lot) of corn. All corn can be prepared as a form of bread (like a tortilla), as soups, or as all-in-one dishes. Examples include a soup called pozole and a steamed and stuffed tortilla dough, called a tamale. Corn is also used to make hot or cold beverages, and even desserts (see Figure 2). In Mexico alone, there are approximately 700 corn-based dishes! The corn-based cuisine from this country is considered an important part of world history and culture by the United Nations (UNESCO ${ }^{3}, 2010$ ).

You may be wondering how so many different dishes can be prepared from a single type of corn. Well, it turns out that there are thousands of different varieties, or types of corn, grouped into hundreds of so-called landraces (varieties of corn that are kept by small-scale farmers, which share similar features and genes). Many of these landraces have existed since pre-Columbian times (before 1492 A.C. [4]). In the Americas alone, approximately 484 landraces have been recorded over the last 100 years [5]. These landraces have been adapted by humans to grow in environments with different soil

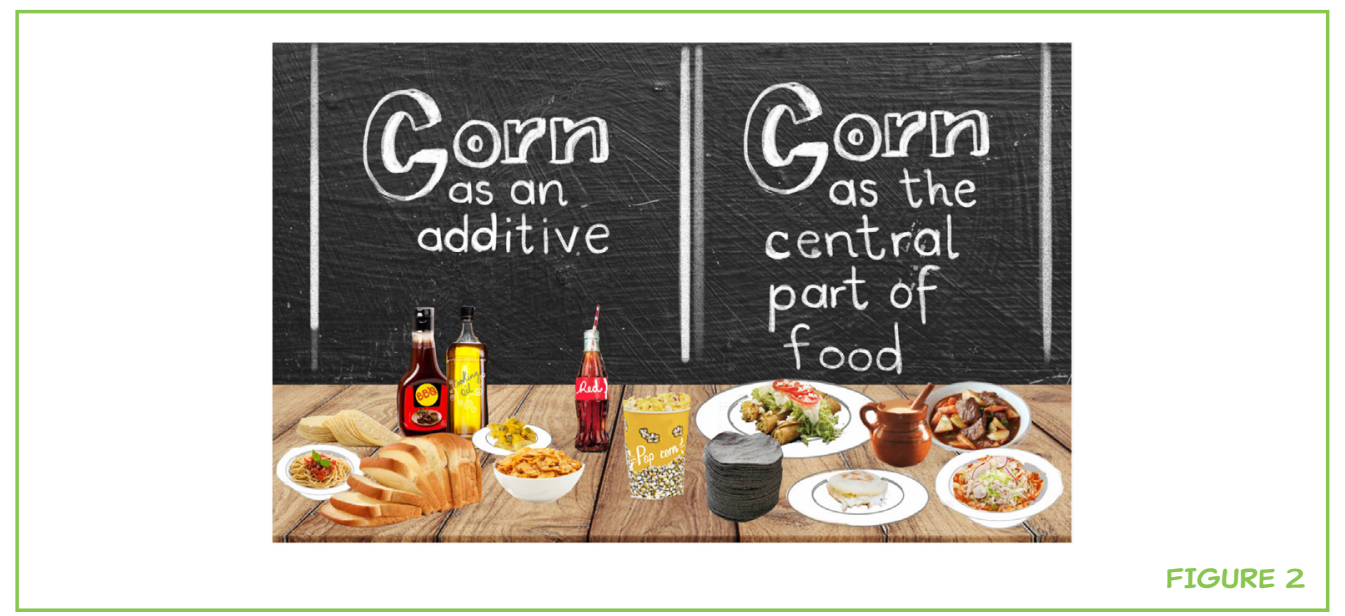


types, altitudes, water availability, and temperatures. In addition, the various landraces of corn have different kernel colors, cob size, and flavor! In the third figure of this article, you will see a map of the American continent with some examples of different landraces, as well as the regions where they were generated $[3,6]$.

\section{CORN LANDRACES, BEAUTIFUL, DIVERSE, AND NECESSARY FOR A CHANGING CLIMATE!}

The fascinating "rainbow" of American corn landraces, shown in Figure 3, is the result of the interaction among three important factors: first, corn's biological qualities (its ability to grow fast and in very diverse weather conditions and types of soil, and its particular gene combinations), second, the environments where different corn varieties have been grown for over 6,000 years, and third, the diverse cultures across the Americas, whose people have been selecting maize varieties for different uses and flavors. Therefore, the huge variety of corn landraces will not always stay the same, because these three factors also change over time. This means that we cannot just go and collect lots of seeds from each variety of corn and store them in a fridge, expecting that the varieties we save will still be able to grow even when the conditions of the world change. This is the reason why we think it is crucial to preserve maize diversity in situ (in the sites where maize varieties are currently being grown), not only in seed banks (seed banks are called ex situ or "outside of their site").

We recently investigated what might happen to corn diversity in Mexico in the future, under different scenarios of climate change. We found that some landraces will thrive well if temperatures increase, but others may disappear [7]. Very importantly, we found that the more we preserve different types of corn landraces, we will be able to better adapt to climate change, reducing the negative impact on agricultural production (less yield per acre), as landraces will be more resistant to variable weather conditions than the commercial corn varieties that are currently being sown in many parts of the world.

Finally, it is also important to make sure that the traditional technologies with which corn has been cultivated for thousands of years are maintained. For example, in the Americas, since before 1492 A.C., maize has been cultivated using a system in which three different crops are grown together, usually beans, pumpkins, and corn are grown together on the same piece of land. This system is called Milpa in Latin America, or the three sisters in some parts of the USA. Different versions of the Milpa system are still used to grow these and other crops in Mexico and other countries in Central America. Even some of the so-called "weeds" that grow in the Milpa are 


\section{FIGURE 3}

Here you can see a map of the American continent showing where corn was domesticated (the Balsas river basin in Mexico). This figure also shows some of the corn landraces that are currently being grown across the continent. Note how different they are in size, shape, and color! Figure by Lucia Campos Peredo and Luis Fernando Sobrado/Zemperi.

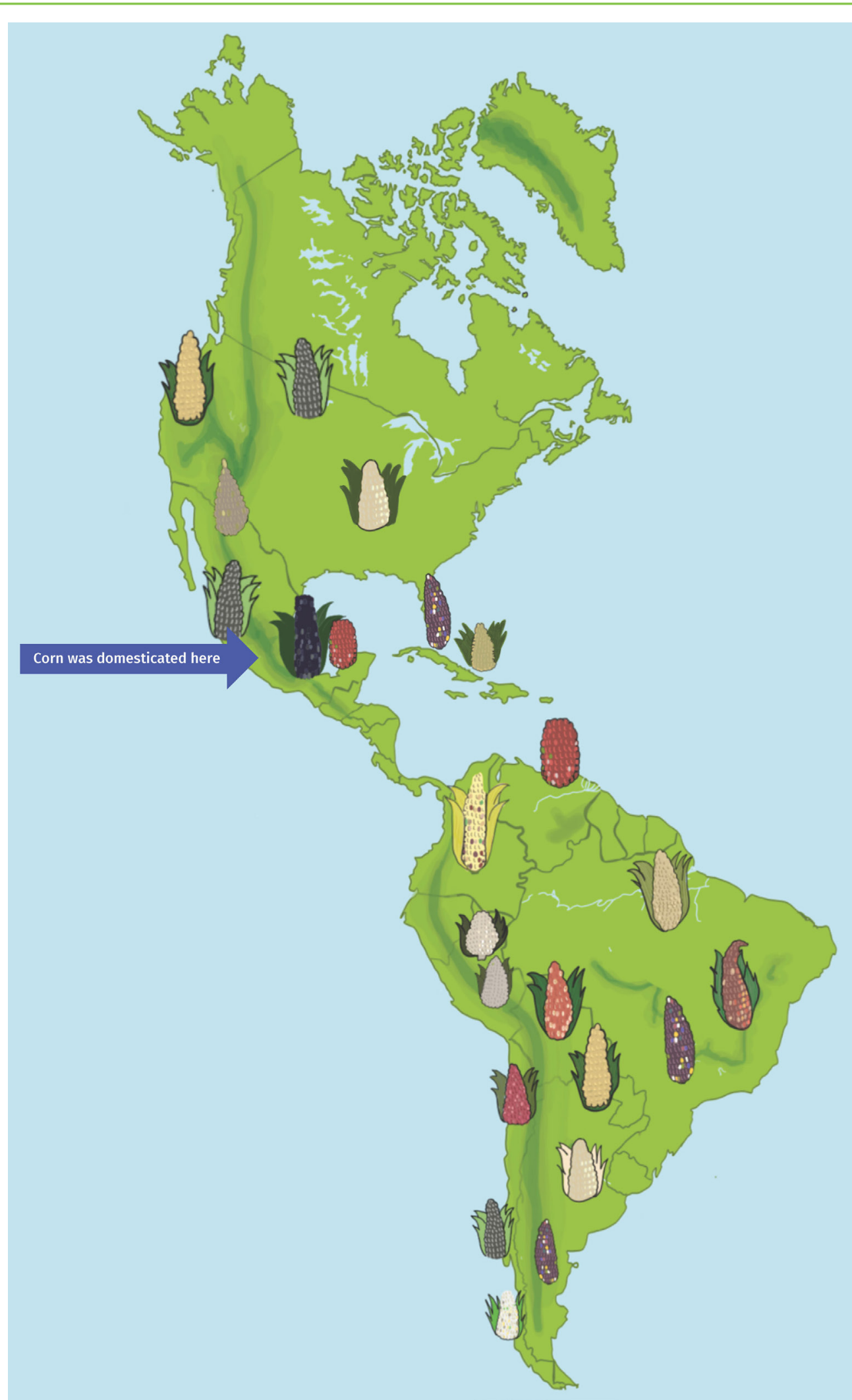

FIGURE 3

tolerated and used for various traditional dishes (turns out that these weeds are both nutritious and delicious!) or used in traditional medicine. The Milpa system makes a better use of critical resources for agriculture: soil, 
physical space, sun, and water. This system is nowadays considered to be a very good method that has fewer negative impacts on the environment than other types of food production methods. By contrast, large-scale industrial farming relies heavily on the use of pesticides, synthetic fertilizers, irrigation, and heavy machinery, which all have huge impacts on the environment. Also, industrial corn agriculture is based on using maize varieties that are very similar genetically and as such, tend to perform poorly under difficult conditions (drought, extreme weather, and insect pests). These varieties tend to displace landraces, sometimes leading to local or complete extinction of local landraces. In addition, some industrial farms use corn varieties that have been genetically modified (GM) in a lab. Genetic modification involves adding genes from other organisms into the corn plant, to help it grow better under certain conditions. These GM varieties can cross with local landraces, potentially damaging them and the farmers who have them. Thus, corn plants that are very similar genetically can be useful in some contexts, but not in others, especially when it comes to diversifying what we eat.

\section{CONCLUSION}

Corn is part of an important plant family called Poaceae. It is the product of human selection over centuries, which made it have unique features such as a big, massive cob with hundreds of kernels. The differences between corn and its weedy relative, teosinte, are the product of humans selecting teosinte variants (mutants). Once corn came to exist, humans further adapted different varieties to different environments. These different varieties, which fed most of the human population before the arrival of the Europeans to the Americas in 1492 A.C., are known as landraces. Corn, together with wheat and rice, remains one of the central components of the human diet. Also, maize is highly versatile, as it has been used for fodder, food, and industrial purposes. When thinking about food, there are countries whose people rely heavily on corn-based dishes, which in turn are prepared using the many corn landraces that small-scale farmers have kept and bred for millennia.

The genetic diversity present in such corn landraces will be very useful to contend with the negative effects of climate change, thus, it is important that we preserve them, and the agricultural systems, such as the Milpa, where they are grown.

So, how many types of corn have you eaten lately? Try more! You will not regret it: corn landraces are pretty, tasty, and a good option for the environment. 


\section{FURTHER READING}

Espinosa de la Mora, D. M. and Lazos Chavero, E. (2016) "Corn: a tireless traveler," in Semillas de Identidad II. Nueve tesoros de México. Mexico: Artes de México, Revista-Libro trimestral. Bilingual edition.

Boutard, A. (2012). Beautiful Corn. America's Original Grain from Seed to Plate. Canada: New Society Publishers, 209.

\section{REFERENCES}

1. Soreng, R. J., Peterson, P. M., Romaschenko, K., Davidse, G., Zuloaga, F. O., Judziewicz, E. J., et al. 2015. A worldwide phylogenetic classification of the Poaceae (Gramineae). J. Syst. Evol. 53:117-137. doi: 10.1111/jse.12150

2. Doebley, J. 2004. The genetics of maize evolution. Annu. Rev. Genet. 38:37-59. doi: 10.1146/annurev.genet.38.072902.092425

3. Benz, B. F. 2001. Archaeological evidence of teosinte domestication from Guilá Naquitz, Oaxaca. Proc Natl Acad Sci U.S.A. 98:2104-6. doi: 10.1073/ pnas.98.4.2104

4. Vigouroux, Y., Glaubitz, J. C., Matsuoka, Y., Goodman, M. M., Sánchez, J., and Doebley, J. 2008. Population structure and genetic diversity of New World maize races assessed by DNA microsatellites. Am. J. Bot. 95:1240-53. doi: 10.3732/ ajb.0800097

5. Serratos, J. A. 2009. El origen y la diversidad del maíz en el continente Americano. México: Greenpeace. Available from: http://www.greenpeace.org/mexico/Global/ mexico/report/2009/3/el-origen-y-la-diversidad-del.pdf

6. Matsuoka, Y., Vigouroux, Y., Goodman, M. M., Sanchez, J., Buckler, E., and Doebley, J. 2002. A single domestication for maize shown by multilocus microsatellite genotyping. Proc Natl Acad Sci U.S.A. 99(9):6080-4. doi: 10.1073/ pnas.052125199

7. Ureta, C., Martínez-Meyer, E., Perales, H. R., and Álvarez-Buylla, E. R. 2012. Projecting the effects of climate change on the distribution of maize races and their wild relatives in Mexico. Glob. Chang. Biol. 18:1073-82. doi: 10.1111/j.1365-2486. 2011.02607.x

SUBMITTED: 17 September 2017; ACCEPTED: 23 November 2017; PUBLISHED ONLINE: 13 December 2017.

EDITED BY: Ana Maria Rocha De Almeida, California State University, East Bay, United States

CITATION: Piñeyro-Nelson A, Sosa-Peredo D, González-Ortega E and Álvarez-Buylla ER (2017) There Is More to Corn than Popcorn and Corn on the Cob! Front. Young Minds 5:64. doi:10.3389/frym.2017.00064 


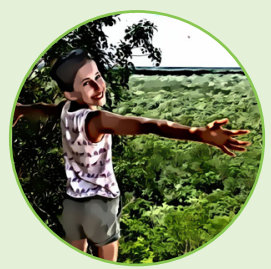

CONFLICT OF INTEREST STATEMENT: The authors declare that the research was conducted in the absence of any commercial or financial relationships that could be construed as a potential conflict of interest.

COPYRIGHT @ 2017 Piñeyro-Nelson, Sosa-Peredo, González-Ortega and Álvarez-Buylla. This is an open-access article distributed under the terms of the Creative Commons Attribution License (CC BY). The use, distribution or reproduction in other forums is permitted, provided the original author(s) or licensor are credited and that the original publication in this journal is cited, in accordance with accepted academic practice. No use, distribution or reproduction is permitted which does not comply with these terms.

\section{REVIEWED BY}

\section{MARIA, AGE: 11}

My name is Maria, and I am 11 years old and live in the Bay Area. I really like hanging out with friends, animals, and playing soccer. I like to be with animals. When I grow up, I want to be the head of the Environmental Protection Agency because I really care about the Earth and want to protect it.

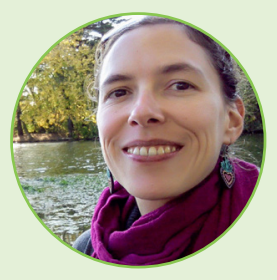

\section{AUTHORS}

\section{ALMA PIÑEYRO-NELSON}

I have been interested on all kinds of organisms since my early childhood, when I would spend many days in a country house observing and manipulating frogs, butterflies, birds, and plants. Lots of kinds of plants! I eventually became a biologist focused on studying them. I am particularly interested in understanding the effects of the interplay between plants and the environment where they grow and how this interaction can impact their development in the short run, but also across long periods of time, favoring diversification and speciation, as well as the emergence of unique shapes and structures. I especially like working with weird and unique plants, and corn is one of them! I have also worked in assessing plant genetic diversity and conservation, as well as the biosafety of crops domesticated in Mexico, which is one of the most biodiverse countries in the world. *almapineyro@gmail.com

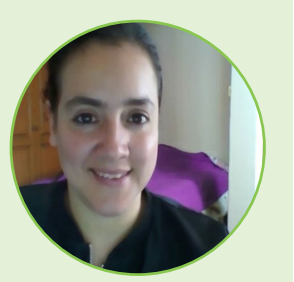

\section{DANIELA SOSA-PEREDO}

I studied biology because I was always interested in understanding how all the natural wonders that surrounded us had originated, from the universe to the tiniest living beings I could see. The origin and evolution of living beings were exciting topics in my career. Little by little I was acquiring knowledge that has helped me to understand a small part of all the questions that have arisen in the way of my academic life. My work has focused on the evolution at the molecular level of living beings and the use of mathematical and computational tools to manage all the information that exists of their genomes, to understand the processes or mechanisms that have led to living beings having their current form. 


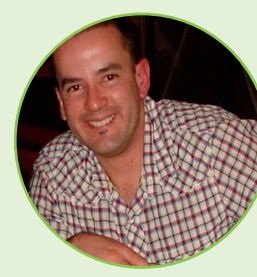

\section{EMMANUEL GONZÁLEZ-ORTEGA}

I am a plant and virus biotechnologist working on Biosafety Research. Through my research activity I have realized that maize (corn) is one of the magical ways in which Mother Nature dialogues with mankind, specifically with the indigenous peoples of the Americas. Currently, all the maize landraces are under risk of disappearing due to many reasons, one of these is the contamination with transgenes (GMOs). My job consists in keeping an eye on peoples' ancient maize for the presence of GMOs using laboratory tools and to explore, along with the communities, different means to preserve maize free of any kind of contamination and having it as good and healthy food for the present and future generations.

\section{ELENA R. ÁLVAREZ-BUYLLA}

Since I was a child I have been fascinated by life! My parents were both life scientists, and we all learned how fascinating it is to learn about plants and animals. My father wanted me to become a medical doctor, but I would rather spend my days watching the fruit trees in our garden, in the South end of Mexico City, observing how they grew flowers and fruits from apparently dry twigs. I have always been fascinated with development, and plants are wonderful to tell us their life histories as they cope with wind, dry soils, or too much or too little sunshine! Their architectures and growth habits make them fascinating creatures to ask questions about development. So, most of my efforts have been devoted to understanding how plants grow and develop. I also like to use mathematical and computer models to understand how multiple components are at play in development. More recently, I have realized that some of the discoveries that we have made in plants can also be useful to understand animal development and how it gets disrupted during illness. So we have lately started to apply our tools and approaches to biomedical issues, such as cancer, that we consider to be a developmental health problem. I am also fascinated by the rich variety of plant species that the people that originally lived in Mexico domesticated and diversified, many of which persist nowadays: over $15 \%$ of the food plants of the whole world come from our Country! We are therefore devoted to helping preserve such important diversity. 